De Glorious Revolution van 1688 herdacht

Recensieartikel door

\title{
G. GROENHUIS
}

De roemrijke omwenteling van 1688 is driehonderd jaar later in Engeland en Nederland, maar ook in de Verenigde Staten van Amerika uitgebreid herdacht. Dat is in zekere zin merkwaardig, omdat de hoofdpersoon van de Glorious Revolution in Groot-Brittannië nooit populair is geweest en ook de meeste van zijn Nederlandse biografen toegeven dat zijn karakter misvormde trekken vertoonde, hetgeen bij meer dan één gelegenheid kwalijke gevolgen had. Willem de Derde was geen aardig mens. Sommige van zijn wandaden waren ernstige misdrijven. Omdat daaraan in de euforie van het jubileum begrijpelijkerwijs weinig aandacht is geschonken, moge het volgende, verre van volledige waslijstje de memorie van de lezer verversen.

In augustus 1672 verroerde Willem III geen vin om te verhinderen dat zijn opvoeder Jan de Witt en diens broer Cornelis het slachtoffer werden van de volkswoede in Den Haag. De aanstichters van de afgrijselijke moordpartij, waaronder de schepen van Banchem, 'een warm vriend van Oranje' ${ }^{1}$, werden door Willem III begunstigd en beloond.

Valt Willems verantwoordelijkheid voor deze moord niet te bewijzen, voor de dood van de ongelukkige kolonel in het Staatse leger Paynwin die in november 1672 zijn post te Nieuwerbrug verliet en op Gouda terugtrok om niet door de over de bevroren waterlinie oprukkende Fransen te worden ingesloten, kan men de Oranjeprins zonder een enkele aarzeling aansprakelijk stellen. De man werd door een krijgsraad tot gevangenisstraf veroordeeld, maar onder druk van Willem III kwamen de rechters op hun vonnis terug en gaven zij Paynwin in tweede instantie de doodstraf die onmiddellijk daarna werd voltrokken.

In augustus 1678 leverde de Prins vier dagen na het sluiten van de vrede van Nijmegen de bloedige slag bij Saint-Denis, hoewel hij wist dat de vrede was getekend. De wanhopige poging van Robert Fruin hem van deze oorlogsmisdaad vrij te pleiten, loopt uit op de erkenning dat het excuus van Willem III zwak was. De nestor der vaderlandse historici schrijft: '... het doet ons leed dat de groote Willem van Oranje zich met zulk een sophistische onderscheiding verdedigt, en dat hij het doet onder aanroeping van Gods heilige naam'².

In februari 1692 werd in opdracht van de stadhouder-koning in het Schotse Glencoe vrijwel de gehele clan van de Mac Donalds in koelen bloede vermoord: mannen, vrouwen en kinderen. Het enige dat een Willem welgezinde biograaf ter zijner verontschuldiging weet aan te voeren is, dat 'he might well have refused to sign' als hij van te voren had geweten dat zijn bevel zo schandelijk zou worden uitgevoerd ${ }^{3}$. Dat alles en nog het een en ander meer heeft niet belet dat de overtocht van Willem III naar Engeland in 1688 en de daaropvolgende kroning van de Oranjeprins en diens gemalin Mary Stuart tot koning en koningin van Engeland, zoals gezegd, in 1988 op grote schaal in herinnering is geroepen. Op tal van plaatsen zijn bijeenkomsten en tentoonstellingen gehouden, waar de gebeurtenissen die drie eeuwen geleden door duizenden Britten en Nederlanders wekenlang in spanning werden gevolgd, tot nieuw leven werden

1 R. Fruin, 'De schuld van Willem III en zijn vrienden aan den moord der gebroeders De Witt', in: Idem, De tijd van De Witt en Willem III. Historische opstellen, I ('s-Gravenhage, 1929) 150.

2 R. Fruin, 'De slag van Saint Denis in verband met den vredehandel van Nijmegen', in: Idem, De tijd van De Witt en Willem III. Historische opstellen, I ( 's-Gravenhage, 1929) 227-228. Men zie ook de uitgebreide bespreking van de kwestie in het proefschrift van J. W. Smit, Fruin en de partijen tijdens de Republiek (Groningen, 1958).

3 Henri en Barbara van der Zee, William and Mary (Londen, 1988) 352. 
gewekt ${ }^{4}$. Meer dan een dozijn publikaties over Willem en Mary en hun tijd, een deel daarvan zowel in het Engels als in het Nederlands, zagen het licht.

Herdenkingen als deze stimuleren de geschiedschrijving. Zij maken niet zelden de publikaties van belangrijk historisch werk mogelijk, doordat in het jubileumjaar geld ter beschikking komt dat anders moeilijk te vinden zou zijn geweest. Daarnaast beijveren uitgevers zich geschiedenisboeken over de te herdenken gebeurtenis op de markt te brengen voor een breed publiek.

Aanvankelijk leek het erop dat de Willem en Mary-herdenking vooral publikaties in de laatstgenoemde categorie zou opleveren. In dit type uitgaven wordt de gebruikelijke annotatie weggelaten om de lezer niet af te schrikken. De Groningse historicus Huussen merkte in augustus 1988 naar aanleiding van de verschijning van een drietal boeken over de Glorious Revolution zonder notenapparaat ietwat geïrriteerd op, dat er kennelijk een 'moderne tendens tot produktie van zogenaamde publieksgerichte, ja zelfs publieksvriendelijke uitgaven' bestond, die de lezer ten onrechte bevoogde en deze bovendien schromelijk onderschatte ${ }^{5}$.

Wie na afloop van de feestelijkheden de oogst aan literatuur over Willem en Mary overziet, kan echter vaststellen dat de door Huussen gewraakte niet geannoteerde publikaties veruit in de minderheid zijn gebleven. Nog geen derde deel van de boeken en artikelen die ik onder ogen heb gehad, verscheen zonder notenapparaat.

Er is in 1988 minder over Willem en Mary geschreven dan over de tijdsomstandigheden waarin zij leefden. Een nieuwe biografie van formaat over Willem III, die de volgens sommigen mislukte levensbeschrijving van Baxter uit $1966^{6}$ zou kunnen vervangen, heeft de herdenking niet opgeleverd. De aandacht ging vooral uit naar het decor waartegen het optreden van de koning-stadhouder en zijn vrouw zich afspeelde. In het bijzonder de huizen en tuinen van Willem en Mary en hun voorname tijdgenoten stonden in het middelpunt van de belangstelling. Men kan de verschenen literatuur naar onderwerp in drie categorieën onderbrengen: boeken en artikelen over de Glorious Revolution, literatuur waarin de hoofdrolspelers en dan vooral Willem III centraal staan en tenslotte publikaties gewijd aan wat hierboven het decor is genoemd. Deze indeling ligt ten grondslag aan de volgende paragrafen.

Het monumentale boek The Age of William III \& Mary II. Power, Politics, and Patronage 1688-1702 dat in het Amerikaanse Williamsburg (Virginia) verscheen en als catalogus bij herdenkingstentoonstellingen in New York en Washington diende, neemt een aparte plaats in. Deze hommage van The College of William and Mary in Williamsburg aan haar stichters is een indrukwekkende poging tot integrale geschiedschrijving van de tijd waarin Willem en Mary leefden, waaraan niet minder dan 47 specialisten uit verschillende landen meewerkten. In de slotparagraaf wordt op deze belangrijke publikatie ingegaan.

\section{DE GLORIOUS REVOLUTION}

In de bundel Willem III, de stadhouder-koning en zijn tijd geeft de Leidse emeritus hoogleraar Schöffer een mooie synthese van de roemrijke omwenteling en haar achtergrond. Hij legt daarin veel nadruk op de internationale betekenis van 'het grote waagstuk' en ziet in de herroeping van

4 Volgens een overzicht in Kleio, XXIX (1988) vi, alleen al in Nederland 19 tentoonstellingen.

5 A. Huussen, "William and Mary': alibi en business', Kleio, XXIX (1988) vi. De door Huussen 'publieksvriendelijk' genoemde uitgaven waren die van Arjen van der Kuijl, De glorieuze overtocht, S. van Raay en P. Spies, In het gevolg van Willem III en Mary en R. Bastiaanse en H. Bots, Glorieuze Revolutie (Zie voor de volledige titels de literatuurlijst van de besproken boeken en artikelen).

6 Het advies van Guido de Bruin (Kleio, XXIX (1988) vi, 13) dat men het boek van S. B. Baxter, William III and the Defense of European Liberty 1650-1702 (Londen, 1966) maar het beste ongelezen kan laten, gaat mij te ver. 
het edict van Nantes van 1598 de sleutel voor het goed verstaan van de gebeurtenissen die volgden. Maar tegelijkertijd accentueert hij dat Willem de Derde zijn schoonvader Jacobus niet alleen verjoeg om Engeland protestants te houden, maar dat het hem er vooral om ging GrootBrittannië actief in de strijd tegen Lodewijk XIV te betrekken. Daarmee haalde de Oranjeprins Engeland uit een isolement en trok hij het land binnen de Europese kring op een moment dat niet beter gekozen had kunnen zijn ${ }^{7}$. Zonder Schöffer te willen tegenspreken, zou ik aan deze visie op de Europese betekenis van 1688 willen toevoegen, dat het in 1988 ook wel goed uit kwam, dat het beeld van Willem III als de 'redder van het protestantisme' wat op de achtergrond raakte. Willems erfgenamen in Noord-Ierland hebben er in onze tijd alles aan gedaan zijn nalatenschap op godsdienstig terrein in diskrediet te brengen. Het onverdraagzame, zich met oranje tooiende protestantisme van dominee Paisly en de zijnen doet menigeen verzuchten, dat Engeland en Ierland er beter aan toe zouden zijn geweest als ' William of Orange ' het protestantisme daar niet had gered.

Ook Raghnild Hatton bezag 1688 in Europees perspectief ${ }^{8}$. Gesprekken met Ernst August van Hannover en Georg Wilhelm van Celle tijdens jachtpartijen in Noord-Duitsland gaven Willem III de zekerheid dat de plaats van zijn naar Engeland te dirigeren troepen ingenomen zou worden door militairen uit Celle en Brandenburg. Ook de houding van keizer Willem Leopold die door het opheffen van het Turkse beleg van Wenen de handen vrij kreeg en de zijde van de anti-Franse coalitie koos, was voor Willem van groot belang.

Hoe gewaagd de overtocht van Willem de Derde naar Engeland was, beschrijft de Utrechtse historicus G. de Bruin in een prikkelend artikel in Kleio. Hij noemt de expeditie waaghalzerij en zeker zo riskant als het uitzenden van de Spaanse Armada honderd jaar eerder. De Bruin meent dat het oordeel over Willem III als de onderneming was mislukt nog veel vernietigender geweest zou zijn dan over Filips II $^{9}$.

De menselijke kanten van het drama staan centraal in het boek van Henri en Barbara van der Zee 1688 Revolution in the Family. Dit goed geschreven verhaal over de gevolgen van 'the queen's great belly' leunt zwaar op een eerder gepubliceerd boek van het echtpaar over Willem en Mary, dat ter gelegenheid van het herdenkingsjaar 1988 opnieuw uitkwam en hierna besproken zal worden. Revolution in the Family heeft minder pretenties dan Willem en Mary. Omdat het boek bedoeld is voor 'the general reader rather than the historian' bevat het geen noten. Een helaas hardnekkig misverstand ligt, zoals ik reeds eerder opmerkte, aan deze zienswijze ten grondslag. Henri en Barbara van der Zee zijn overigens de enige herdenkers bij wie het licht niet vrijwel uitsluitend op de figuur van Willem de Derde valt. In beide boeken vindt de lezer een met veel invoelingsvermogen geschreven portret van Willems echtgenote. De Van der Zees laten met name in hun beschrijving van Mary Stuart als regerend koningin van Engeland tijdens de langdurige perioden van afwezigheid van de stadhouder-koning heel mooi zien dat zij over niet geringe kwaliteiten moet hebben beschikt.

Eveneens zonder notenapparaat is de Glorieuze overtocht van de hand van Arjen van der Kuijl. Rijk geillustreerd en prettig leesbaar geschreven, kan men er veel aardige bijzonderheden in vinden. Dat de Bill of Rights het absolute koningschap verving door een constitutioneel, beperkt koningschap, zoals Van der Kuijl op bladzijde 71 schrijft, lijkt mij een te sterke formulering van de betekenis van de revolutie van 1688. De in de wet aan Willem en Mary opgelegde

7 I. Schöffer, 'Het grote waagstuk. De overtocht van Prins Willem III naar Engeland in 1688', in: A. G. H. Bachrach, e. a,, ed., Willem III, de stadhouder-koning en zijn tijd (Amsterdam, 1988) 9-30. De tekst geeft abusievelijk 1589 als jaartal voor het edict van Nantes (14).

8 Raghnild Hatton, "1688' in Europees perspectief', Oranje-Nassau Museum Jaarboek (1988) 5-29.

9 Guido de Bruin, 'Willem III naar Engeland. Een heugelijke gebeurtenis?', Kleio, XXIX (1988) vi, 5-14. 
beperkingen brachten een gevoelige slag toe aan de beginselen van het 'droit divin', maar voordat de principes van de constitutionele monarchie daarvoor in de plaats kwamen, zou er nog heel wat water door de Thames stromen. Groot-Brittannië kende nog jarenlang een vorm van 'mixed government', waarin één van de basiselementen van de constitutionele monarchie: een soeverein die boven de partijen en de politiek staat, volledig ontbrak. Nog enige eeuwen zou de koning zich volop in het politieke krachtenveld laten gelden. Ook Willem III 'was very far from being a 'constitutional monarch' in the modern sense ...' ${ }^{10}$.

Glorieuze Revolutie. De wereld van Willem \& Mary hoort eigenlijk in de eerste groep niet thuis. De tweetalige uitgave, waarin de tekst in twee kolommen synchroon in het Nederlands en in het Engels is afgedrukt, biedt een beknopte levensbeschrijving van Willem III met een laatste hoofdstuk over de wereld van Willem en Mary als toegift. Het verhaal van de roemrijke omwenteling neemt in het geheel een ondergeschikte plaats in. Het boek verscheen als inleiding bij de catalogus van de grote overzichtstentoonstelling in de Nieuwe Kerk in Amsterdam.

Glorieuze Revolutie bevat mooi beeldmateriaal, voor een groot deel in kleurendruk, maar de tekst is mager en een notenapparaat is niet aanwezig. De beschrijving van het rampjaar 1672 wekt ten onrechte de indruk dat Willem III Holland redde door op tijd de dijken door te steken. In werkelijkheid kwam de inundatie uiterst moeilijk en eerst na geruime tijd tot stand en was Hollands overleven veeleer het gevolg van strategische fouten aan Franse kant dan van het militair vernuft van een de waterlinie uitbuitende stadhouder. Fruins boek over de oorlog van 1672 dat in 1972 uitkwam en overtuigend aantoont dat in het bijzonder de trage Franse opmars Holland redde, ontbreekt dan ook in de bibliografie waarmee deze bijdrage van Bastiaanse en Bots aan de Willem en Mary-herdenking wordt afgesloten.

\section{DE HOOFDROLSPELERS}

Bij Penguin Books verscheen ' to coincide with the 300th anniversary of the Glorious Revolution of 1688 ' in 1988 een herdruk in pocketuitgave van het lijvige boek over Willem en Mary dat het schrijversechtpaar Henri en Barbara van der Zee in 1973 publiceerde. Het vlot geschreven boek berust op een uitvoerig literatuur- en bronnenonderzoek, maar vertoont niettemin een aantal gebreken. Zo zijn de auteurs niet steeds gelukkig in de keuze van hun zegslieden. De lange bibliografie maakt, vooral daar waar het om Nederlandse literatuur gaat, een verouderde indruk. Roorda komt bijvoorbeeld niet één keer op hun lijst voor.

Het boek bevat feitelijke fouten en slordigheden. 'The castle Teylingen' (13) lag niet bij Breda, maar onder Voorhout in Zuid-Holland. Maria Theresia, de vrouw van Lodewijk XIV, was niet de dochter van Filips V van Spanje (34), maar van Filips IV. De vrouw van raadpensionaris Johan de Witt heette Wendela Bicker, niet Wandela Becker (49). De vrede van Westminster die een einde maakte aan de derde Engelse oorlog werd niet in 1673 (95) gesloten, maar in 1674.

Auteurs met de goed Nederlandse naam Van der Zee zouden ook Nederlandse geografische aanduidingen niet zo moeten verhaspelen: Giertruedenberg voor Geertruidenberg (47), Miden voor Muiden (78) bijvoorbeeld. Het constant verkeerd gebruik van de term raadspensionaris in plaats van raadpensionaris wijst niet op grote vertrouwdheid met de Nederlandse historische literatuur van enigszins recente datum. In dat verband viel ik ook over de identificatie van de op 31 december 1966 op 79-jarige leeftijd overleden Pieter Geyl als 'a modern Dutch historian' (77).

10 K.H. D.Haley, 'William III', in: Bachrach, Willem III, de stadhouder-koningen zijn tijd, 48. Een heldere uiteenzetting over de tussenperiode van 'mixed government', in: Lewis Namier, 'Monarchy and the Party System', in: Idem, Personalities and Powers (1955) 13-39. 
Maar tegenover deze tekorten staat, dat de Van der Zees geen hagiografie schreven, maar de lezer in staat stellen zichzelf een oordeel te vormen over Willem en Mary. Het feilloos gevoel voor het tekenende detail van het echtpaar blijkt daarbij een voordeel dat niet onderschat mag worden. Blijven de naamloze soldaten die Willems gewaagde invasie uitvoerden in de meeste beschrijvingen van de Glorious Revolution naar het woord van Brecht 'im Dunkel', de Van der Zees laten zien dat de arme sloebers, waaronder 200 zwarten uit Suriname, voor Willem III niet meer waren dan pionnen in het Europese spel. Tijdens de mars naar Londen, zo vertellen zij bijvoorbeeld, demonstreerde Willem de discipline in zijn leger door twee soldaten om een kleinigheid ter dood te brengen. ' He publicly hanged two soldiers for stealing a chicken, telling the others that they were paid well enough not to need to steal' ${ }^{11}$.

Van hoog gehalte is de schets die K. H. D. Haley uit Sheffield in twintig bladzijden van Willem III weet te geven ${ }^{12}$. Hij noemt de stadhouder-koning ambitieus, maar niet zelfzuchtig, een calvinist, maar tegelijkertijd pragmatisch tolerant. Als mens was de Oranjeprins volgens Haley hard en koel. Onderhevig aan wisselende stemmingen was het geen uitzondering dat hij in woede ontstoken zijn bedienden lijfelijk tuchtigde. Was het zijn eenzame jeugd die hem parten speelde en de Prins moeilijk sociale contacten deed leggen? Het is vaak verondersteld, maar Haley merkt nuchter op dat Willems jongensjaren niet ongelukkiger waren dan die van Lodewijk XIV die op vijfjarige leeftijd zijn vader verloor of van Karel II en Jacobus II van Engeland wier vader in 1649 op het schavot het leven liet. Dat frustraties uit Willems jeugd van invloed waren op zijn latere leven, wordt niet door Haley ontkend, maar hij wijst ook op positieve elementen. Zo is er zijns inziens tot nu toe onvoldoende gelet op de betekenis die de omgang van de Engelse ambassadeur met Willem III op de vorming van de Prins heeft gehad in de perioden waarin de Engelsman Sir William Temple gezant in Den Haag was (1668-1670 en 1674-1679).

Als koning van Engeland in de jaren negentig was Willem III tobbend met een zwakke gezondheid, voortdurend overbelast waardoor hij slechts korte-termijn-doelen kon nastreven. Dit leidde er onder meer toe dat hij in Schotland 'was blamed by some for 'the massacre of Glencoe' in his name'. Haley is hier met een excuus dat veel lijkt op de wijze waarop de Van der Zees de moord op de Mac Donaldclan vergoeilijken mijns inziens te vriendelijk voor de stadhouder-koning ${ }^{13}$.

In dezelfde bundel waarin Haley over Willem III schrijft, bespreekt P. J. A. N. Rietbergen oorlog, politiek en economie in Noordwest-Europa ten tijde van Willem III, schetst J. A. H. Bots de vooravond van de Verlichting, schrijft P. G. Hoftijzer over de culturele betrekkingen tussen Groot-Brittannië en de Nederlandse Republiek en gaat A. G. H. Bachrach in op 'de literaire dimensie'. In een nawoord zien Bots en Rietbergen in het optreden van Willem III nog het meest 'een gezonde mengeling van eigen geloofsovertuiging en een groot ontwikkeld gevoel voor politieke opportuniteit' (157).

W. Troost gaf het 'sommier en waerachtigh verhael ' uit dat een anonieme zeventiende-eeuwse auteur schreef over de eerste reis van Willem III naar Engeland in 1670-1671. De Orangistische auteur was goed geïnformeerd, maar liet niet het achterste van zijn tong zien. Hij beperkte zich 'tot een weinig diepgaand en vooral feitelijk relaas van de belangrijkste gebeurtenissen tijdens de reis'. Het verslag wilde vooral propaganda voor de Prins maken. Luid prijst de schrijver 's Prinsen deugdzaamheid en eenvoud. 'Dat is noch een braef Heer; die heeft met de pronckerijen

11 Henri and Barbara van der Zee, William and Mary, 258.

12 K. H. D. Haley, 'William III', in: Bachrach, Willem III, de stadhouder-koning en zijn tijd, 31-51.

13 Ibidem, 45. 
niet te schaffen' merkten volgens de rapporteur de dames in Engeland op (42). Aardig, maar gezien het karakter van de bron kan men er nauwelijks conclusies aan verbinden.

Het gemeente-archief van Den Haag herdacht de Glorious Revolution met een tentoonstelling in het Haags historisch museum gewijd aan de luisterrijke intocht van Willem III in de stad in 1691. Het boek Koning-stadhouder Willem III Triomfator dat daarbij verscheen heeft de indrukwekkende ontvangst van de held van de Boyne door regering en magistraat tot onderwerp. De tekst van René W. Chr. Dessing is zowel in het Nederlands als het Engels afgedrukt en bestaat voor een groot deel uit verklarende toelichtingen bij de historisch-allegorische voorstellingen waarop de Hagenaars werden vergast. De vorm van de ontvangst in Den Haag in 1691 gaat terug op de Blijde Inkomsten die in Brabant sinds het midden van de veertiende eeuw voorkwamen. De Hooghe en Vennekool die de verschillende erepoorten ontwierpen, lieten zich naar de mode van hun tijd door Franse voorbeelden inspireren. De door de anonieme schrijver van het reisverslag uit 1670-1671 zo geprezen afkeer van de Prins van 'pronckerijen' ging blijkbaar niet zover, dat Willem III zijn medewerking aan de triomfale intocht weigerde.

Het Joods historisch museum in Amsterdam wijdde een tentoonstelling aan de familie Lopes Suasso, financiers van Willem III. Daniël Swetschinski en Loeki Schönduve beschreven de levens van enige vooraanstaande Suasso's en gingen in op de relatie met Willem III. Ook dit boek bevat naast elkaar een Nederlandse en een Engelse versie van de tekst. Vast staat dat Francisco Suassso bevriend was met de stadhouder-koning en hem aanzienlijke geldsommen leende. Of hij, zoals de mythe wil, de overtocht van Willem III naar Engeland financierde, blijft een onbeantwoorde vraag.

\section{HET DECOR}

De ironie van de geschiedenis wil, dat het leven van Willem en Mary, getekend door de niet aflatende strijd met Frankrijk, zich afspeelde in een tijd die steeds meer onder invloed van de Franse cultuur stond. De komst van tienduizenden hugenoten na de herroeping van het edict van Nantes in 1685 was een belangrijke factor in die beïnvloeding, maar zeker niet het begin. Zij dateerde al vanaf het eerste kwart van de zeventiende eeuw en tekende zich vooral na 1650 steeds scherper af. Naast de latijnse scholen kwamen in de steden Franse scholen op, in de gereformeerde kerk werd op verschillende plaatsen in het Frans gepreekt. In Utrecht trok het stadsbestuur in het begin van de zeventiende eeuw geld uit om Franse schoolmeesters over te halen zich in de stad te vestigen ${ }^{14}$. In Nijmegen ontving dominee Coutsius sinds 1607 een toelage boven zijn tractement omdat hij 'int fransois' diensten hield voorde Franstaligen van het garnizoen ${ }^{15}$. Meer nog dan in school en kerk bepaalden Franse cultuurelementen de wereld waarin Willem en Mary en de zich aan de aristocratie spiegelende regentenstand verkeerden.

Een van de uitgeweken hugenoten die 'vorm gaven aan het deftig bestaan' der weigestelden, was de ontwerper Daniel Marot. Hij vluchtte in 1686 uit Frankrijk naar Holland waar hij als 'dessinateur' in dienst van het stadhouderlijk hof trad. In die functie had Marot een groot aandeel in de totstandkoming van Het Loo. Marot overleefde Willem III een halve eeuw. In die periode werkte hij onder meer aan de Haagse stadspaleizen. Zijn werk in de hofstad is het thema van het schitterend uitgegeven boek over de architectuur en de inrichting van Haagse herenhuizen onder redactie van Koen Ottenheym, Willem Terlouw en Rob van Zoest. Het boek bestaat uit twee delen. In deel I bespreken Rob van Zoest en Xander van Eck een aantal voorname woonhuizen, schrijft Willem Terlouw over de rijke interieurs en behandelt Marten Loonstra de koepel van

14 E. P. de Booy, Kweekhoven der wijsheid (Zutphen, 1980) 138.

15 G. Groenhuis, De predikanten (Groningen, 1977) 143. 


\section{G. GROENHUIS}

Fagel. Een bijdrage van L. J. van de Klooster gaat in op een brief van Jacob Godefroy baron van Boetzelaer aan Johan Hendrik graaf van Wassenaar Obdam uit 1711, waarin de eerste interessante mededelingen over Daniel Marot doet. Een beschouwing van Frits T. Scholten over Marot als ontwerper van grafmonumenten sluit het eerste deel af.

In deel II passeren 108 ontwerpen van huizen, interieurs en tuinen van Daniel Marot de revue. Hoewel de redactie niet pretendeert met deze studie het standaardwerk over Marot van M. D. Ozinga te vervangen, heeft het boek, ook door het voortreffelijk beeldmateriaal, het karakter van een naslagwerk en de verdienste het oeuvre van Marot voor een groot publiek toegankelijk te hebben gemaakt.

Huizen en tuinen uit de tijd van Willem en Mary staan eveneens centraal in het boek van Stefan van Raay en Paul Spies In het gevolg van Willem \& Mary dat niet minder fraai is uitgevoerd dan het hiervoor besproken boek. Behalve Nederlandse krijgen nu ook Engelse huizen en tuinen aandacht. Dat gebeurt in het hoofdstuk 'The Royal Progress' aan de hand van de rondreis die Willem III tussen 17 oktober en 10 november 1695 door Engeland maakte. Het prachtige Chatsworth House bevond zich niet onder de kastelen die de stadhouder-koning aandeed, maar de samenstellers van het boek namen het gelukkig wel in hun beschrijving van de 'royal progress' op. De bouwheer, William Cavendish, de vierde graaf van Devonshire, was als overtuigde Whig een van de voornaamste architecten van de Glorious Revolution. Hij werd in 1694 door Willem III tot hertog verheven, maar buiten de politiek gehouden. Als koning kon ook Willem met de ideeën van de Whigs niet uit de voeten. Aan de beschrijving van Van Raay en Spies had mijns inziens een opmerking over de indrukwekkende bibliotheek in het huis moeten worden toegevoegd. Imponerender nog dan het majestueuze paleis, is het parklandschap dat Lord Devonshire om het huis liet aanleggen. De eerste hertog stierf kort nadat de laatste vleugel van Chatsworth House werd voltooid in 1707.

Mede dankzij een toegevoegd register is dit voor een breed publiek geschreven boek een waardevolle gids geworden voor allen die een verkenningstocht zouden willen maken langs de schitterende behuizingen van Willem en Mary en hun aristocratische tijdgenoten. De schrijvers noemen de interesse van het koninklijk paar voor kunst en cultuur aantoonbaar, maar relativeren die belangstelling door erop te wijzen dat zij ook het karakter had van een vanzelfsprekende standsverplichting. Een voorbeeldfunctie als patroon vervulden zij volgens hen niet.

Een derde plaatwerk over de koninklijke woonomgeving: De tuinen van Willem en Mary is een verzamelbundel van niet minder dan achttien deskundigen uit Engeland en Nederland. Het boek heeft onder het geweld van zoveel auteurs enigszins geleden. De tekst spreekt zichzelf af en toe tegen en bevat een aantal overlappingen. Jammer is ook, dat pas in het tweede deel een technische uiteenzetting over de tuin wordt gegeven, waarin termen worden uitgelegd die al in het eerste deel worden gebruikt. Niettemin valt ook in dit boek veel te genieten. De conclusie ten aanzien van de Franse invloed op de Hollandse tuin ten tijde van Willem en Mary luidt: ideeën uit Frankrijk werden ingepast in een Nederlandse traditie die al uit de tijd van Frederik Hendrik stamde. Het bestaan van Hollandse tuinen in Engeland wordt door een van de auteurs, John Harris, een mythe genoemd. Met uitzondering van de koninklijke tuinen in Hampton Court zou de Hollandse tuin overzee geen navolging hebben gehad. Het vormsnoeiwerk, de buxushaagjes en andere 'kinderachtige onzinnigheden ' in de parterren, die volgens Engelse schrijvers typerend waren voor de 'Dutch Garden', waren helemaal geen typisch Hollandse kenmerken.

Die opvatting wordt tegengesproken in het speciaal dubbelnummer van de Journal of Garden History dat met een Engelse en Hollandse tekst naast elkaar als catalogus bij tentoonstellingen in het paleis Het Loo en Christie's in Londen diende. John Dixon Hunt toont daarin overtuigend aan dat de door Engelse auteurs veroordeelde kneuterigheid van extravagant gesnoeide heesters 
wel degelijk terugging op Hollandse voorbeelden. Hij citeert Brereton die in de Republiek een tuin aantrof, waarin natuurgetrouw in buxus alle houdingen van een soldaat en een kapitein te paard waren afgebeeld. Ook wijst Hunt op het feit hoe veelvuldig, de moeilijkheden van het veelal golvende Engelse landschap in aanmerking genomen, het spelen met water in de vorm van grachten, waterpartijen en bijbehorende koepeltjes in Groot-Brittannië naar Hollands voorbeeld werd gekopieerd. Volgens Hunt gedijde de Nederlandse stijl vooral in de kleinere tuinen. 'Oxford college gardens are an excellent case in point' schrijft hij ${ }^{16}$.

Tot het decor behoorden naast de tuinen de vele schilderijen die vooral de Engelse paleizen opsierden. Alleen al in Whitehall hingen 650 schilderijen en miniaturen. Willem III had zeker oog voor deze kunstschatten. Bij een brand in Kensington in 1691 gold zijn eerste zorg de schilderijen. Maar een kenner was hij waarschijnlijk toch niet. Anders dan zijn grootvaders Frederik Hendrik en Karel I bracht Willem III geen collectie bijeen. Wel liet hij voor de aankleding van Het Loo een dertigtal schilderijen uit de Engelse koninklijke verzameling naar Nederland halen. De Nederlandse huizen van Oranje waren na de dood van Amalia van Solms in 1675 geplunderd door de erfgenamen in Duitsland. Meer dan 200 schilderijen uit de voortreffelijke collectie Noord- en Zuidnederlandse schilderijen van Frederik Hendrik verdwenen over de oostgrens.

Na het overlijden van de stadhouder-koning in 1702 probeerden de Engelsen de 'geleende' kunstwerken terug te krijgen. De Engelse gezant Stanhope verscheen met een gespecialiseerde lijst van schilderijen die door zijn regering werden opgeëist. Een daarvan was het bekende dubbelportret dat Anthonie van Dijck van Willem II en zijn kindbruidje in 1641 schilderde. Na veertien jaar touwtrekken bleven de schilderijen uiteindelijk in Nederland, waardoor de aandoenlijke afbeelding van Willem II en Mary Stuart nu in het Rijksmuseum te Amsterdam te bezichtigen is. Het Mauritshuis, Nederlands mooiste museum, organiseerde in 1988 de tentoonstelling 'Betwiste schilderijen van de koning-stadhouder' en gaf in samenwerking met de voormalige staatsdrukkerij SDU de bijzonder fraaie catalogus Paintings from England uit. Daarin wordt onder meer de boeiende speurtocht naar de schilderijen op de lijst van Stanhope beschreven.

Waren de boeken van Willem en Mary ook decorstukken? Voor Willem III zullen zij inderdaad niet meer dan wandversiering zijn geweest. De Oranjeprins was geen lezer. Hij vertoefde het liefst in de vrije natuur en was op zijn best tijdens jachtpartijen en veldslagen. Zijn betekenis voor de Oranje-Nassaubibliotheek is dan ook gering geweest. Veel meer dan de opdracht geven de boekerij te catalogiseren heeft de Prins niet bijgedragen. Niettemin organiseerde de Koninklijke Bibliotheek in Den Haag een expositie van boeken uit de Oranje-Nassaubibliotheek ten tijde van Willem m. De bij die gelegenheid uitgegeven studie Boeken van Oranje maakt duidelijk dat Maurits en Frederik Hendrik de grondleggers van de bibliotheek waren. Hun belangstelling ging in het bijzonder uit naar boeken over de krijgskunst.

\section{BESLUIT}

In de hierboven besproken literatuur wordt de tijd van Willem en Mary van veel kanten belicht. De deelname van zeer veel musea en wetenschappelijke instellingen aan de herdenking heeft geleid tot de uitgave van een aantal prachtig uitgevoerde boeken over de wereld waarin de koning-stadhouder en zijn vrouw leefden. Over de huizen en tuinen, de schilderijen en de boeken uit hun tijd is na het jubileumjaar aanmerkelijk meer te lezen dan daarvoor. Een nieuwe,

16 John Dixon Hunt, 'De invloed van Nederlandse tuinkunst in Engeland', Journal ofGarden History (1988) ii-iii,56. 
samenvattende biografie over Willem III heeft de grootscheepse viering van de Glorious Revolution echter niet opgeleverd. Maar daar staat tegenover dat met The Age of William III \& Mary II een standaardwerk over het tijdperk ter beschikking is gekomen.

Zoals in de inleiding van dit artikel ai is opgemerkt, neemt de bijdrage van The College of William and Mary in Williamsburg, Virginia een bijzondere plaats temidden van de herdenkingsliteratuur in. Robert P. Maccubbin en Martha Hamilton Phillips, de redacteuren van het boek, stelden een 'reference encyclopedia and exhibition catalogue' van hoge kwaliteit samen, die door de uitgever niet ten onrechte als 'a landmark publication without any equivalent for other historical periods' werd aangekondigd. Onder de 47 contribuanten treffen we enkele specialisten aan van wie ook in andere herdenkingsboeken bijdragen verschenen. Bijvoorbeeld die van K. H. D. Haley over de buitenlandse politiek en die van John Dixon Hunt over de EngelsHollandse tuin. Maar voor de overgrote meerderheid van de auteurs geldt dat niet.

Uit Nederland leverden Auke Sj. van der Goot (Groningen) met 'Huygens's Final Years as Dutch Secretary', Dirk de Vries (Leiden) met 'Dutch Cartography', Lyckle de Vries (Groningen) met 'Dutch Painting', Christiaan Schuckman (Utrecht) met 'Dutch Prints and Printmaking', Arend H. Huussen jr. (Groningen) met 'Censorship in the Netherlands' en J. J. V. M. de Vet (Nijmegen) met 'The Image of William \& Mary in Dutch Poetry' een aandeel in het grote werk.

De bijdragen zijn verdeeld over vijf secties: Politics, Religious History and Law; Cartography, Military History, Trade and Finance; Philosophy, Science, Medicine and Education; Visual Arts; en Music, Literature and Publishing. De artikelen zijn bondig geschreven, aan de auteurs werd gevraagd essays bij te dragen waarop de vakman zich kan verlaten, maar die ook voor de niet ingewijde zijn geschreven. Omdat het boek ook als tentoonstellingscatalogus dienst moest doen, is het rijk geillustreerd. Na introducties van onder meer de ambassadeurs van GrootBrittannië en Nederland in de Verenigde Staten en een voorwoord van de twee redacteuren, volgt een reeks afbeeldingen in kleur. De samenstellers van het boek vonden prachtig materiaal in de Henry E. Huntingdon Library in San Marino in Californie, dat in de achttiende eeuw verzameld werd door Richard Bull.

Uiteraard is aandacht geschonken aan de betekenis van 1688 voor Amerika. Die blijkt gering. Voor de Amerikaanse koloniën veranderde er door de Glorious Revolution weinig. David S. Lovejoy schrijft in het opstel 'The Glorious Revolution in America' dat de kolonisten moesten leven met het gegeven dat de koloniën 'the king's business' waren en ook na 1688 geregeerd bleven overeenkomstig de wensen des konings en niet volgens de 'English constitution at home ${ }^{17}$.

In het in deze eeuw schitterend gerestaureerde koloniale Williamsburg herinnert het College of William and Mary aan de stadhouder-koning en zijn vrouw. In 1691 willigde Willem III het verzoek van Virginië in waarbij om een vrije school en een hogeschool voor de opvoeding van haar jeugd werd gevraagd. Twee jaar later zetten koning en koningin hun handtekening onder het handvest dat de oprichting en het bestuur van het College of William and Mary regelde ${ }^{18}$. De betekenis van de Amerikaanse bijdrage aan de herdenking van 1688 ligt vooral in de veelzijdige benadering van de tijd van Willem en Mary. Hoe deze tot een beter begrip van het doen en laten der personae dramatis kan leiden, is misschien het best aan de hand van een voorbeeld duidelijk te maken. Tijdens de opmars van het invasieleger naar Londen liet Willem III, zoals al is gezegd, om de discipline in zijn leger te demonstreren, twee soldaten opknopen

17 Roben P. Maccubbin, Martha Hamilton-Phillips, ed., The Age of William III \& Mary II, 76.

18 Parke Rouse, 'Their Majesties' Royal College in Virginia', in: Maccubbin, The Age of William III \& Mary II, 209-

217; Legacy from the Past. A Portfolio of Eighty-Eight Original Williamsburg Buildings (Williamsburg, 1975). 
wegens het stelen van een kippetje. In onze ogen een wel zeer zware straf voor een klein vermogensdelict. Maar hoe zagen de tijdgenoten dat? De bijdrage van de Canadese J. M. Beattie, 'The Criminal Trial in England', aan The Age of William III \& Mary II geeft een duidelijk antwoord op die vraag. Zijn artikel begint met de geschiedenis van William Gillett die op 21 februari 1694 voor de rechtbank van Old Bailey in Londen werd gebracht, omdat hij zes hoeden uit de winkel van Richard Bosley zou hebben ontvreemd ter waarde van 30 shilling. Hoewel de verdachte bezwoer dat hij de hoeden op straat had gevonden, werd hij op het getuigenis van twee winkelbedienden schuldig verklaard en veroordeeld tot de strop. Hij kwam er genadiger af dan Willems soldaten, want hij kreeg gratie en werd niet opgehangen maar als dwangarbeider naar de Amerikaanse koloniën gestuurd. Maar dat maakt zijn geschiedenis nauwelijks minder illustratief.

Hoe belangrijk het boek van Maccubbin en Hamilton-Philips voor het ' verstehen' van Willem en Mary ook moge zijn, de biografie die niet verscheen, kan de studie niet vervangen. Ondanks de gedurfde collectieve inspanning van zoveel specialisten het tijdperk van de koningstadhouder te belichten, blijft de hoofdfiguur wat in het duister staan. Willem de Derde blijft in veel opzichten ongrijpbaar. Een raadselachtig man, noemde Roorda hem in het portret dat hij in 1979 van hem gaf $^{19}$.

19 D. J. Roorda, 'Willem III, de koning-stadhouder', in: C. A. Tamse, ed., Nassau en Oranje in de Nederlandse geschiedenis (Alphen aan den Rijn, 1979) 157.

\section{Lijst van besproken literatuur}

Bachrach, A. G. H., e. a.,ed. Willem III', de stadhouder-koning en zijn tijd (Amsterdam: De Bataafsche Leeuw, 1988,169 blz., f39,50, ISBN $906707201 \mathrm{X}$ ).

Bastiaanse, R., Bots, H. Glorieuze Revolutie. De wereld van Willem \& Mary. Glorious Revolution. The World of William \& Mary ('s-Gravenhage: SDU, 1988, 95 blz., f24,50, ISBN 9012058104 (handelseditie), ISBN 9012058554 (tentoonstellingseditie)).

Doorn, M. van, ed. Koning-stadhouder Willem III, triomfator. De triomfale intocht in Den Haag in 1691 ('s-Gravenhage: Haags Historisch Museum, 1988, 84 blz.).

Jacques, D., Horst, A. J. van der. De tuinen van Willem en Mary (Zutphen: Terra, 1988, xiii + 224 blz., f49,90, ISBN 90 62553559 ).

Journal of Garden History, VIII (1988) ii-iii (Amsterdam: Thoth, 1988, vi + 341 blz., f59,50, ISBN 906868015 3).

Koning-stadhouder Willem III triomfator. Speciaal nummer van Kleio, XXIX (1988) vi.

Kuijl, A. van der. Glorieuze overtocht. De expeditie van Willem III naar Engeland in 1688 (Amsterdam: De Bataafsche Leeuw, 1988, 80 blz., f29,90, ISBN 906707187 0).

Kuijpers, J., Renting, A. D., ed. Boeken van Oranje. De Oranje-Nassaubibliotheek ten tijde van Willem III ('s-Gravenhage: Koninklijke Bibliotheek, 1988, 103 blz., f20,-, ISBN 906259084 5).

Leeuwen, R. van, ed. Paintings from England. William III and the Royal Collections (Den Haag: Mauritshuis, SDU, 1988, 128 blz., f37,50, ISBN 901206007 9).

Maccubbin, R. P., Hamilton-Philips, M., ed. The Age of William III \& Mary II. Power, Politics, and Patronage 1688-1702. A Reference Encyclopedia and Exhibition Catalogue (Williamsburg: The college of William and Mary, New York: The Grolier Club, Washington: The Folger Shakespeare Library, 1989, xxxii + 416 blz., \$26,95, ISBN 00962208108 ).

Oranje-Nassau Museum Jaarboek (Zutphen: De Walburg Pers, 1988, ISBN 906011598 8).

Ottenheym, K., e. a., ed. Daniel Marot. Vormgever van een deftig bestaan. Architectuur en interieurs van Haagse stadspaleizen (Zutphen: De Walburg Pers, 1988, 118 blz., f79,-, ISBN 906011601 1).

Raay, S. van, e. a. In het gevolg van Willem III \& Mary. Huizen en tuinen uit hun tijd (Amsterdam: De Bataafsche Leeuw, 1988, 179 blz., f39,50, ISBN 906707170 6).

Swetschinski, D., Schönduve, L. De familie Lopes Suasso, financiers van Willem III (Zwolle: Waanders, Amsterdam: Joods historisch museum, 1988, 88 blz., f29,50, ISBN 906630142 2).

Zee, H. en B. van der. 1688. Revolution in the Family (Londen: Penguin Books, 1988,256 blz., £4.95, ISBN 014008354 $5)$.

Zee, H. en B. van der. William and Mary (2de druk; Londen: Penguin Books, 1988,532 blz., £5.95, ISBN 014010691 X). 


\section{ALGEMEEN}

W. J. van der Dussen, Filosofie van de geschiedwetenschappen (Serie wetenschapsfilosofie; Leiden: Martinus Nijhoff, 1988, 126 blz., f22,50, ISBN 906890097 8).

Voor zover het vak geschiedfilosofie buiten Nederland nog bestaat, is deze anti-kentheoretisch ingesteld. Kentheoretische vragen als 'wat is historische waarheid?', 'hoe moet het geschiedkundig oordeel gefundeerd worden?, 'wat is de logische structuur van een historische redenatie of verklaring ' of ' hoe verhouden zich in de geschiedbeoefening taal en werkelijkheid? ' acht men irrelevant of zelfs misleidend waar het gaat om het verkrijgen van inzicht in de aard van de geschiedbeoefening. Liever schrijven Amerikaanse geschiedfilosofen over de eigenaardigheden van de historische tekst als representatie van het verleden, over zijn esthetische, tropologische, rhetorische of zelfs zijn semiotische aspecten. De meeste Nederlandse geschiedfilosofen staan daarentegen afwijzend tegenover deze anti-kentheoretische, op de historische tekst gerichte benadering. Dat deze tegendraadse houding wel degelijk tot vruchtbare resultaten leiden kan, werd onlangs nog bewezen door het voortreffelijke proefschrift van C. Lorenz. En ook dit meest recente boek van Van der Dussen is niet alleen een originele samenvatting van reeds bestaande opvattingen, maar voegt op een aantal plaatsen aan die bestaande kentheoretische inzichten een nieuwe dimensie toe.

Een van de beste voorbeelden van een originele behandeling is Van der Dussens introductie van C. S. Peirces abductiebegrip in de geschiedfilosofie. Abductie is een redenatieschema dat verwant is aan, maar toch verschilt van zowel inductie als van deductie. Men zou abductie het beste kunnen omschrijven als het creatief formuleren van hypotheses. Creatief, omdat bij abductie van de gegevens naar de hypothese een overstap gemaakt wordt die noch door regels of door een bepaald algoritme gesteund of bepaald wordt. Wel is het zo dat vanuit de abductief gewonnen hypothese bepaalde deducties gedaan kunnen worden, die empirisch testbaar zijn. De manier van denken van detectives-zoals men die althans in de betere detectiveromans aantreft (men kan denken aan Eco's De naam van de roos) — is paradigmatisch voor het abductieve redeneren. Maar Van der Dussen wijst er op dat de abductie ook een belangrijke rol zal spelen in de geschiedkundige oordeelvorming.

Een andere boeiende suggestie in dit boek is om Vaihingers filosofie van het 'alsof' te gebruiken als model voor de relatie tussen historische taal en historische werkelijkheid. Van der Dussen bekritiseert het instrumentalisme omdat in het instrumentalisme, althans in Van der Dussens versie daarvan, de historische taal moet dienen ter verklaring van het bewijsmateriaal in plaats van andersom. Wordt evenwel de historische taal en de daarin zich ontwikkelende historische beeldvorming opgevat als een 'alsof', als een tentatieve 'fictie' van de historische werkelijkheid, dan blijven de juiste verhoudingen bewaard. Want dan dient inderdaad het bewijsmateriaal weer om een bepaalde voorstelling van het verleden (zoals uitgedrukt in een bepaald 'alsof') tot stand te brengen.

Niet steeds zal Van der Dussens betoog iedereen overtuigen. Zo brengt P. F. Strawsons performatieve waarheidstheorie Van der Dussen ertoe om het (historisch) feit niet te zien als een stand van zaken in de historische werkelijkheid maar als een uitspraak daarover. Daartegen pleit dat wij wel van 'onware uitspraken' maar niet van 'onware feiten' spreken kunnen — blijkbaar liggen feiten en uitspraken toch niet op hetzelfde niveau. Van der Dussen ondervangt dit bezwaar door slechts van 'feiten' te willen spreken in het geval van algemeen aanvaarde 